\title{
Social Quality: A Way to Measure the Quality of Society
}

\author{
Pamela Abbott • Claire Wallace
}

Accepted: 22 May 2011/Published online: 3 June 2011

(C) The Author(s) 2011. This article is published with open access at Springerlink.com

\begin{abstract}
In this paper we suggest a way to measure the well-being of society based upon our own development of the Social Quality model. The Social Quality model has the advantage of being sociologically grounded as a measure of the well-being of society and the individuals within it. We test our model of Social Quality against life satisfaction as an indicator of how successful it is in delivering these aspirations. The model was tested on all European countries using the European Quality of Life Surveys in 2003 and 2007 and was found to explain a large amount of variance, which was consistent across time and space. We suggest that it is possible to operationalise this model using small number of variables, ones that are frequently used in comparative surveys and this should enable the quality of society to be measured in a parsimonious and effective way.
\end{abstract}

Keywords Social quality · Quality of life · European comparison · Subjective well-being · Life satisfaction

"It's time we admitted there's more to life than money, and it's time we focused not just upon GDP but upon GWB-general well-being" said Prime Minister David Cameron in 2005 and now he has announced that he is seeking ways to measure well-being in Britain (Guardian 15th November, 2010). Measuring well-being has become something that has attracted increasing interest in recent years as French President Nicolas Sarkozy invited Nobel Prize Winning economists, Amartya Sen and Joseph Stiglitz to consider the same issue. In the case of France, this resulted in a substantial report released in 2009 Commission on the measurement of economic performance and social progress (www.Sen-Stiglitz-Fitoussi.fr).

P. Abbott · C. Wallace $(\bowtie)$

University of Aberdeen, Aberdeen, Scotland, UK

e-mail: Claire.wallace@abdn.ac.uk

Present Address:

C. Wallace

European Quality of Life Surveys, Dublin, Ireland 
The examples above are indicative of an increasing interest in measuring the well-being of society as a measure of social progress going beyond economic indicators (Halpern 2010). But how can it be measured? This is usually done by a measure of subjective wellbeing using questions about life satisfaction or other similar variables frequently included in surveys of individuals. Most statistical experts would see one indicator as being a rather thin measure of the well-being of society as a whole, even if it has proved to be a good measure of social progress over time. More robust statistical analysis might use a range of indicators to measure satisfaction across different domains (satisfaction with work, satisfaction with family, satisfaction with housing etc.) in order to produce a composite score. The Sen-Stiglitz-Fitoussi Report recommends a panoply of indicators rather than a single measure to capture the complexity of well-being. Diener and Suh in a comprehensive review of indicators identify three philosophical approaches, each associated with a different set of variables (Diener and Suh 1997). However, there is potentially a large array of subjective and objective indicators that could be included. How can we choose amongst them?

The common criticism of life satisfaction, as well as related indicators such as happiness or malaise as measures of well-being, is that they measures only individual states of mind based upon psychological theories, which is not necessarily helpful for measuring the quality of society as a whole. Another criticism is that they use a range of variables or domains, which are a-theoretical nature and with a variety of indicators simply added together. What is needed is a more sociological approach for measuring the quality of society more generally. Such an approach has been suggested by proponents of the Social Quality model (Beck et al. 1997). Until now, however, this has only been applied in very limited ways to particular societies and has not been developed as a model that can be applied cross-nationally using standardised indicators. The purpose of this paper is to develop a model of Social Quality that can be applied using a small set of standardised and easily accessible indicators for measuring the quality of life in different societies. Elsewhere we have developed this model for Eastern European and African societies, where it has proved to have substantial explanatory power. Here we test it on 27 European societies surveyed in 2003 and 2007 in the European Quality of Life Survey in order to demonstrate that it is stable across time and space and could therefore be used to measure the quality of society more generally. The theoretical basis for Social Quality has been elaborated elsewhere and we sketch this briefly below, but the main purpose of this paper is to look at how this theory (as we have interpreted it) can be applied through using a set of survey indicators and whether it can explain life satisfaction in European countries at different points in time.

\section{Theoretical Basis of the Social Quality Model}

In this paper we use Social Quality as a sociologically grounded theoretical as a measure of the quality of a society, building on our previous work where we demonstrated that Social Quality can be used to derive indicators for explaining variation in subjective satisfaction (Abbott and Wallace 2010; Abbott et al. 2011). We validate the model against subjective satisfaction as this is the key indicator of peoples preferred way of life in order to demonstrate that a great deal of the cross national variation in subjective well-being can be understood by using the model of Social Quality that we have developed (Richardson et al. 2008; Veenhoven 1999). We agree with Veenhoven (2008) that subjective satisfaction is something that should be of interest to sociologists as it is clearly socially determined and 
is strongly influenced by the position of individuals and groups in a society's opportunity structure and should be useful for measuring the effectiveness of social policies (Bohnke 2006; Veenhoven 2002, 2008; Watson et al. 2009). However, as sociologists we are interested in the social influences on life satisfaction or subjective well-being and this is where the Social Quality model can make an important contribution by showing the link between individual agency and social structure (Giddens 1984; Mills 1954). Ultimately the challenge is to understand what type of society can maximize citizens' welfare in order for them to develop their own capabilities (Abbott and Wallace 2010; Abbott et al. 2011; Nussbaum and Sen 1993; Sen 1993, 1999).

The Social Quality Model is a multi-dimensional construct derived from sociological theory. Society is envisaged as the outcome of the articulation of social and systems integration and as providing the context for agency (Giddens 1984; Lockwood 1992; Phillips 2006). Social Quality provides a complex methodological and analytical framework for describing and explaining the quality of society, explicitly challenging the view that economic growth alone inevitably results in a higher quality of life for individuals and societies (although we recognise the link between economic, political and social governance). Subjective satisfaction is a key indicator of the quality of the social system and provides the basis for understanding what makes a liveable society (Beck et al. 1997; Veenhoven 2008). People are seen as embodied social beings, located in a given time and place, active in meeting their own needs in that context, and they need to be empowered to do so. Subjective well-being alone cannot measure this.

However, it is important to distinguish between societal well-being and individual wellbeing, although the two are inextricably linked. The former provides the context in which individuals are able to flourish and grow-the capability structure. The latter concept of individual well-being is measured through subjective satisfaction, but it is discursively constituted through social interactions and cultural meanings. The quality of society influences social engagement and the higher the quality of a society the more options people have to plan and make arrangements for the future and the higher we would expect their life satisfaction to be. There is a strong relationship between economic performance and the quality of governance in a society and individuals perception of the quality of their society (Bohnke 2006; Watson et al. 2009). Agency and the ability to build capabilities is dependent on social and geographical location as well as individual perceptions of the opportunities available to them which are in turn influenced by their position in the societal opportunity structures. However, we would expect societal quality to have a strong impact upon life satisfaction as measured by subjective assessments - a good society should have satisfied people.

The Social Quality approach measures the quality of the social context of everyday life which is seen as the outcome of the dialectical relationship between the formation of collective identities and the self-realisation of the human subject. It provides the essential link between need, action and policies between economic and social development. It measures the extent to which the quality of daily life provides for an acceptable standard of living, taking account of the structural features of societies and their institutions as assessed by reference to their impact on citizens. It conceptualizes 'the social' as the space created by the interaction between the economic structure and the social structure and between structure and agency.

The Social Quality model identifies four fields: economic security, social cohesion, social inclusion and the conditions for social empowerment. These are expressed as four quadrants which are the product of the relationship between global processes and biographical processes on the one hand and that between systems, institutions and communities (Gesellschaft and Gemeinschaft) on the other (Lockwood 1992). The four domains 
with which we are concerned are firstly socio-economic security or ensuring people have the resources over time to be able to cope with daily life, enjoy a dignified lifestyle and take advantage of the opportunities available to citizens. It is about more than having employment that pays a decent wage-it is about economic security across the life course and having access to welfare services that ensure it. The second domain of social cohesion is the glue that binds a society together and creates trust (Phillips 2006). It provides for the rule of law essential for social participation and provides for social stability and continuity. An adequate level of social cohesion is one which enables citizens 'to exist as real human subjects, as social beings' (Beck et al. 1997: 284). The third domain of social inclusion in is the degree to which people are and feel integrated in institutions, organisations and social systems. It includes intimate relationships with kin and friends as well as membership of looser networks. It is a complex concept and requires recognising the need for pluralistic social inclusiveness (Phillips 2006) in order to facilitate the inclusion of individuals and communities. The fourth domain of conditions for social empowerment require that the objective conditions exist and that individuals have the ability to make use of the opportunities available to them. Empowerment encompasses both the means by which people can be empowered - their levels of health and education-but also their subjective feelings of agency. The model can be represented in the diagramme below (Fig. 1):

The basis for Social Quality is provided by public policies, including economic policy, labour market policy and social policy. Whilst the policy context shapes Social Quality it is also shaped by it in the way that different human and social needs are fed back into the policy process. A public policy informed by Social Quality would include: economic policies that provide for independence; labour market policies that opened the way for participation; social policies for securing individual dignity, for fostering social solidarity, and; empowerment (enabled by education and health policies as well as consultative processes) to shape the space for action. Social Quality provides the basis for a metatheory for developing public policy and for its implementation and enables us to identify policies that might be relevant in this respect.

For the purposes of this analysis we take a number of indicators as being indicative of the four main aspects of Social Quality: socio-economic security, social cohesion, social inclusion and social empowerment. Whilst these indicators are not exhaustive, they can

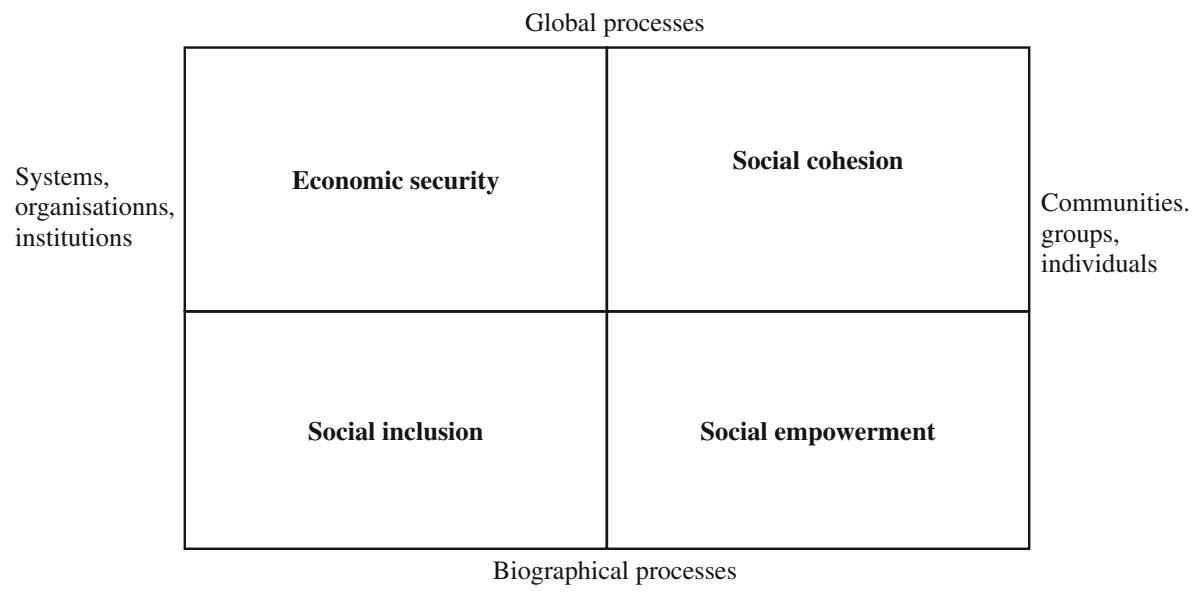

Fig. 1 The social quality model 
give an indication of the relative weight of the four domains. However, the Social Quality model as developed elsewhere also tends to include large numbers of indicators for each quadrant and these often vary with different country analysis and different authors. Whilst we could discuss which were the most appropriate variable for measuring each quadrant, we need to find ones that are consistently derived, are parsimonious and can be easily accessed from standard survey in order to be efficient and affordable. The ones we have suggested here are intended to be part of this debate.

We are concerned to understand how robust the model is across time and across different European regions, and we have therefore compared the 2003 and the 2007 European Quality of Life Surveys and we have looked at the influence of countries on the model. If the model is robust across time and space, we can say that this is a good way of measuring Social Quality.

The dependent variable is subjective well-being, because as we have argued above, it is a good indicator of how effective the model is in delivering satisfaction for citizens. There are wide variations in subjective well-being across European countries as we show in Table 1. Here we can see that in both 2003 and 2007 the Nordic countries have the highest levels of subjective well-being, whilst the Eastern and Southern countries have the lowest. This is consistent with findings from other surveys too (Haller and Hadler 2006). In this paper we want to test whether the Social Quality and life satisfaction are determined by the same factors in all societies or whether it differs between countries and across time. We would expect those societies with better Social Quality to have higher levels of life satisfaction.

\section{Methods}

The 2003 and 2007 European Quality of Life Surveys serve as the data bases for the empirical analysis. In the 2003 a 27 country survey was carried out covering the then EU countries, plus three candidate countries. In 2007 the survey covered 31 countries, the 27 EU member states, three candidate countries and Norway. In 2003 the questionnaire was fielded by Intomart GFK and in 2007 by TNS Opinion, these organisations having responsibility for assigning national institutes to draw random samples and conduct the interviews in each country. In both years the survey collected comparable information on household and family composition, working conditions, social position, income and standard of living, time use and work-life balance, housing conditions, political participation, social support and social networks, health and subjective well-being. Some changes were made to the questionnaire between waves, with additional questions being asked in 2007, which we discuss later.

In 2003 around a 1,000 people aged 18 years and over were interviewed face-to-face in each country, except in the smaller countries of Luxembourg, Malta, Estonia, Cyprus and Slovenia (600 respondents). In 2007 about 1,000 people in most countries, with 1,500 people being interviewed in the larger countries (France, Italy, Poland and the UK) and 2000 in Germany. In 2003 the national response rate varied widely between $30 \%$ in Spain and a questionable $90 \%$ in Germany and in 2007 the overall response rate was 58\% but with a wide variation from just over $33 \%$ in the UK to $88 \%$ in Romania. In both years the data was carefully checked and in the course of the data processing, recoded variables, breakdown variables, indices and macro variables were added and the data weighted (for more detail on methodology see Anderson et al. 2009). In this paper we use the data for the $27 \mathrm{EU}$ member states in 2003 and in 2007 (some of which were Candidate Countries in 2003). 
Table 1 Life satisfaction in EU countries 2003 and 2007

\begin{tabular}{|c|c|c|c|c|c|c|c|c|}
\hline \multirow[t]{2}{*}{ Country } & \multicolumn{2}{|c|}{ Satisfaction 2003} & \multirow[t]{2}{*}{ Rank } & \multicolumn{2}{|c|}{ Satisfaction 2007} & \multirow[t]{2}{*}{ Rank } & \multirow{2}{*}{$\begin{array}{l}\text { Differences } \\
\text { means } \\
2003-2007\end{array}$} & \multirow{2}{*}{$\begin{array}{l}\text { Change } \\
\text { in rank }\end{array}$} \\
\hline & Mean & SD & & Mean & $\mathrm{SD}$ & & & \\
\hline Austria & 7.75 & 1.788 & 4 & 6.84 & 2.162 & 15 & -.91 & -11 \\
\hline Belgium & 7.43 & 1.652 & $8=$ & 7.51 & 1.739 & 8 & +.08 & $=$ \\
\hline Bulgaria & 4.42 & 2.315 & 27 & 4.90 & 2.013 & 27 & +.48 & $=$ \\
\hline Cyprus & 7.19 & 2.108 & 14 & 7.05 & 2.217 & 14 & -.14 & $=$ \\
\hline Czech Republic & 6.41 & 2.103 & 18 & 6.52 & 2.121 & 18 & +.11 & $=$ \\
\hline Denmark & 8.40 & 1.555 & 1 & 8.47 & 1.715 & 1 & +.07 & $=$ \\
\hline Estonia & 5.81 & 2.023 & 23 & 6.65 & 1.950 & 17 & +.84 & +6 \\
\hline Finland & 8.09 & 1.524 & 2 & 8.17 & 1.359 & 3 & +.08 & -1 \\
\hline France & 6.90 & 1.639 & 15 & 7.25 & 1.717 & 10 & +.35 & +5 \\
\hline Germany & 7.28 & 1.927 & $11=$ & 7.09 & 2.287 & 13 & -.19 & -2 \\
\hline UK & 7.35 & 1.900 & 10 & 7.27 & 2.039 & 9 & -.08 & +1 \\
\hline Greece & 6.74 & 2.237 & 17 & 6.51 & 2.069 & 21 & -.23 & -4 \\
\hline Hungary & 5.89 & 2.187 & 21 & 5.51 & 2.250 & 26 & -.38 & -5 \\
\hline Ireland & 7.67 & 1.743 & 5 & 7.59 & 1.892 & 6 & -.08 & +1 \\
\hline Italy & 7.20 & 1.616 & 13 & 6.48 & 1.823 & 21 & -.72 & -8 \\
\hline Latvia & 5.48 & 2.125 & 24 & 6.03 & 2.154 & 24 & +.55 & $=$ \\
\hline Lithuania & 5.33 & 2.154 & 25 & 6.20 & 2.124 & 23 & +.97 & +2 \\
\hline Luxembourg & 7.66 & 1.928 & 6 & 7.96 & 1.819 & 4 & +.30 & +2 \\
\hline Malta & 7.28 & 1.973 & $11=$ & 7.54 & 1.972 & 7 & +.26 & +4 \\
\hline Netherlands & 7.53 & 1.263 & 7 & 7.87 & 1.235 & 5 & +.33 & +2 \\
\hline Poland & 6.18 & 2.20 & 19 & 6.79 & 2.079 & 16 & +.61 & +3 \\
\hline Romania & 6.11 & 2.281 & 20 & 6.46 & 2.058 & 22 & +.35 & -2 \\
\hline Slovakia & 5.59 & 2.363 & 24 & 6.56 & 2.041 & 18 & +.97 & +6 \\
\hline Slovenia & 7.01 & 1.964 & 14 & 7.15 & 1.952 & 12 & +.14 & +2 \\
\hline Spain & 7.43 & 1.756 & $8=$ & 7.23 & 1.760 & 11 & -.20 & -3 \\
\hline Sweden & 7.81 & 1.710 & 3 & 8.35 & 1.630 & 2 & +.54 & +1 \\
\hline Portugal & 5.87 & 2.217 & 22 & 6.12 & 1.998 & 25 & +.25 & -3 \\
\hline Mean EU 27 & 6.75 & 2.217 & & 7.36 & 6.386 & & & \\
\hline Mean FCC & 5.77 & 2.290 & & 6.31 & 2.164 & & +.53 & \\
\hline Mean EU 15 & 7.40 & 1.857 & & 7.42 & 3.529 & & +.02 & \\
\hline
\end{tabular}

In constructing the model we have selected as indicators variables from a rich data set as indicative of the underlying constructs we are measuring. Undoubtedly we could have explained more of the variance if we had included additional indicators but this would have made the model more difficult to interpret and was not necessary for our purpose here. We were also using data that had not been specifically collected for our purpose and there were no good indicators of social capital, something which would have been an important indicator of social inclusion, had they been available.

In order to test our whether the Social Quality model remained consistent between 2003 and 2007 we carried out a series of OLS regressions with subjective satisfaction as the independent variable, controlling for age and gender for 2003 and 2007 . We entered the variables in four blocks: economic security; social cohesion; social inclusion, and; 
conditions for empowerment. Finally, using Sweden as the reference, we tested our model to see it held for all the countries. We tested the model for multicollinearity and found it to be satisfactory as the tolerance of no variable was below .4 (Tarling 2009). The levels of single order correlations between the dependent and independent variable were also tested and found to be acceptable.

We should note that there were a number of changes in the questionnaire between 2003 and 2007 and this makes the comparison of some individual variables impossible but does not impact on our ability to construct comparable models. In 2003 there was not a question on trust in government but we were able to compute a scale from two questions: trust in the government to deliver state pensions, and; trust in the government to deliver social benefits. The response options for the question on self evaluation of health changed but this does not impact on the ability for cross-society comparison, because we compare only across countries and respondents within each time period.

\subsection{The Dependent Variable}

The dependent variable in the regression analysis was the satisfaction scale- 'All things considered how satisfied would you say you are with your life these Days?'-coded 1 (least satisfied to 10 most satisfied). General satisfaction has been shown to be a relatively stable cognitive construct that is a good indicator of individuals overall satisfaction with life although it increased in the region between 2003 and 2007 (Table 1). This was mainly due to an increase in Eastern and Central European countries with economic growth, increased political stability and civic society developing (Abbott and Wallace 2009).

\subsection{Modelling the Quality of Society}

To construct our model we use a number of variables as indicators of the underlying constructs we were interested in.

For economic security we used:

1. The equivalised income of the household in Euros;

2. A deprivation index constructed from a series of question concerning the ability to buy essential goods and services as a measure of relative deprivation coded from "can afford all if want to cannot afford any" of the following items could be afforded: keeping the home adequately warm; paying for a weeks holiday away from home; replacing worn-out furniture; a meal with meat, chicken or fish every second day; buying new cloths and having friends or family for a drink or meal at least once a month (CA $2003.859,2007.843$ ).

3. Inability to afford to buy basic food as a measure of absolute poverty. Coded 1 yes, 2 no;

4. Assessment of adequacy of the income of the household as a more subjective measurer of relative deprivation. Coded on a six point scale from very easily to with great difficulty.

In selecting these variables we have included subjective and objective perceptions of economic security and relative as well as absolute indicators of poverty.

For social cohesion we used:

1. General trust - a measurer which together with trust in government has been shown to be a good indicator of social cohesion (Halpern 2010; Phillips 2006); 
2. Trust in government using the Trust in Government Scale (2003) which was computed from the answers to the extent of trust in state pension system; trust in state social security system (CA 2003 .782).

3. Perception of social conflict. The Conflict Scale was computed from the answers to whether or not tension exists between, poor and rich, management and workers, men and women, and different racial and ethnic groups (CA 2003 .722, 2007 .755).

Social cohesion is intended to indicate how the society as a whole coheres together. Therefore generalised trust, as well as trust in government gives an indication of how the society works as a whole. This is reinforced by using perceptions of social conflict as a way of understanding how divided or cohesive the society might be.

For social inclusion we used

1. The answers to a series of questions on social support (when ill, need advice, feel depressed, urgently need to borrow money) entered as dummies coded 0 no support/1 support;

2. The answers to a series of questions on frequency of contact with friends and relatives dichotomised to frequent contact (once a week or more) other. As we were interested in social inclusion we coded those without relatives as other. Coded 0 no frequent contact/1 frequent contact;

3. Married/living with a partner. Coded no 0 , yes 1 ;

4. Vote in elections as an indicator of identification with the society Coded no 0 , yes 1 ;;

5. Membership of a political party/trade union as the only measure in the data set for formal social capital available in both years Coded no 0 , yes 1 .

6. The extent to which the respondent felt left out of society as a subjective indicator of social inclusion coded on a four point scale from completely agrees, feels left out to disagrees completely.

We interpret social inclusion as meaning how the individual is included into the society. Hence contact with friends and relatives and having someone to turn to for support would be one measure of what kind of connection the individual has to their surroundings. Similarly, being married is a way of being included in social networks and a basic kind of community. The next two sets of indicators (voting and membership of political party or trade union) provide a different sense of how an individual may connect with the body politic and with their environment more generally through formal mechanisms. The final variable is more a psychological one indicating how far the respondent feels left out of society. Hence, social inclusion draws upon a more heterogenous set of indicators but they all measure the way in which the individual is connected to their community and society.

For the conditions for social empowerment we used;

1. Highest level of education as an indicator of cultural capital;

2. Self evaluation of health which has been shown to be a reasonably good measurer of health status. Coded from in good health to in poor health;

3. The extent to which respondents feels that "life has become so complicated that you can't find you way" coded on a four point scale from completely agree to completely disagree.

The indicators for social empowerment use first of all health and education as a condition for empowerment, from which people can act upon their environment and the third indicator measures psychological circumstances-how empowered an individual feels. 


\section{Multiple Regression Analysis}

We used the enter method as we wanted to validate the model. In 2003 the model explained $45.9 \%$ of the variance and in $200740 \%$, which is a substantial amount and indicates that our Model is a good measure of life satisfaction. In both years the strongest contributions to the variance explained were made by economic variables and those measuring the conditions for empowerment but the social cohesion and social inclusion variables also made a noticeable contribution. In both years strong contributions to the variance explained were made by the Deprivation Scale, the inability to make ends meet, general trust in other people, the Trust in Government Scale, feeling left out of society, feeling that life is too complicated and health status. Gender made a significant contribution to the variance

Table 2 Explaining general satisfaction 2003 in EU and candidate countries

\begin{tabular}{|c|c|c|c|}
\hline \multirow[t]{2}{*}{ Variables } & \multicolumn{3}{|c|}{ Model 5} \\
\hline & B & Beta & SE \\
\hline Constant & 7.044 & & .351 \\
\hline Age & .001 & .011 & .001 \\
\hline Gender & .201 & $.047 * *$ & .029 \\
\hline \multicolumn{4}{|l|}{ Economic } \\
\hline HH Income & .000 & .007 & .000 \\
\hline Deprivation Scale & -.209 & $-.183 * *$ & .011 \\
\hline Make ends meet & -.305 & $-.195^{* *}$ & .015 \\
\hline Food & .121 & $.020^{*}$ & .046 \\
\hline \multicolumn{4}{|l|}{ Social cohesion } \\
\hline General trust & .157 & $.168 * *$ & .007 \\
\hline Trust Government & -.098 & $-.076^{* *}$ & .009 \\
\hline Conflict scale & .001 & .001 & .007 \\
\hline \multicolumn{4}{|l|}{ Social Inclusion } \\
\hline Support ill & .004 & .000 & .114 \\
\hline Support advice & .015 & .001 & .095 \\
\hline Support depressed & .056 & .005 & .086 \\
\hline Support money & .071 & .011 & .046 \\
\hline Married & .250 & $.057 * *$ & .030 \\
\hline Contact parents & .012 & .010 & .009 \\
\hline Contact children & .017 & -.016 & .008 \\
\hline Contact friends & .045 & $.023 * *$ & .013 \\
\hline Relatives/friends letter etc. & .102 & $.019 *$ & .039 \\
\hline Feel left out & .324 & $.125 * *$ & .019 \\
\hline Vote & -.083 & -.015 & .038 \\
\hline Meeting TU etc. & -.054 & -.009 & .040 \\
\hline \multicolumn{4}{|l|}{ Empowerment } \\
\hline Life complicated & .295 & $.141 * *$ & .016 \\
\hline Health & -.262 & $-.139 * *$ & .015 \\
\hline Education & -.154 & $-.048 * *$ & .023 \\
\hline Adjusted $R^{2}$ & .459 & & \\
\hline
\end{tabular}


Table 3 Explaining general satisfaction 2007 EU countries

\begin{tabular}{|c|c|c|c|c|}
\hline \multirow{31}{*}{$\begin{array}{l}\text { Table } 3 \text { Explainıng general } \\
\text { satisfaction } 2007 \text { EU countries }\end{array}$} & Variables & $\mathrm{B}$ & Beta & SE \\
\hline & Constant & 6.411 & & .258 \\
\hline & Age & .006 & $.048 * *$ & .001 \\
\hline & Gender & .116 & $.028 * *$ & .026 \\
\hline & Economic & & & \\
\hline & HH Income & .000 & -.010 & .000 \\
\hline & Deprivation Scale & -.169 & $-.136^{* *}$ & .010 \\
\hline & Make ends meet & -.291 & $-.183 * *$ & .013 \\
\hline & Food & .164 & $.024 * *$ & .047 \\
\hline & Social cohesion & & & \\
\hline & General trust & .088 & $.102 * *$ & .006 \\
\hline & Trust Government & .097 & $.118 * *$ & .006 \\
\hline & Conflict scale & .015 & $.019 *$ & .005 \\
\hline & Social inclusion & & & \\
\hline & Support ill & -.516 & $-.031 * *$ & .108 \\
\hline & Support advice & -.049 & -.004 & .082 \\
\hline & Support depressed & -.113 & -.011 & .067 \\
\hline & Support money & -.198 & $-.032 * *$ & .039 \\
\hline & Married & .302 & $.070 * *$ & .028 \\
\hline & Contact parents & -.005 & -.001 & .030 \\
\hline & Contact children & .001 & .000 & .029 \\
\hline & Contact friends & .009 & .002 & .033 \\
\hline & Relatives/friends letter etc. & .176 & $.027 * *$ & .041 \\
\hline & Feel left out & .248 & $.119 * *$ & .015 \\
\hline & Vote & -.041 & -.015 & .017 \\
\hline & Meeting TU etc. & .006 & .001 & .040 \\
\hline & Empowerment & & & \\
\hline & Life complicated & .262 & $.146^{* *}$ & .013 \\
\hline & Health & -.297 & $-.136^{* *}$ & .015 \\
\hline & Education & -.038 & -.010 & .024 \\
\hline & Adjusted $R^{2}$ & .400 & & \\
\hline
\end{tabular}

$* p<.01 ; * * p<.001$

explained in both years but the betas were very low. Age made a significant contribution in 2007 but again, the beta was very low. This suggests that the Model is a general one in terms of age and gender (Tables 2 and 3) and is stable across time.

We then tested the model to see if it was a general one for all the countries by entering the countries as dummy variables with Sweden as the control. The variance explained increased significantly in both years but by a relatively small amount. In 2003 it increased by two percent to $47.9 \%$ and in 2007 by $2.5-42.5 \%$ (Tables 4,5 ). A number of the countries contributed to the variance explained significantly but the betas were generally very low. Of note is that Bulgaria is more satisfied and Hungary less satisfied than would be predicted by the model in both years and the betas are stronger but still relatively low. We therefore conclude that the model is a general one and is stable across countries as well as across time. 
Table 4 Country differences in subjective satisfaction (OLS regression) 2003 EU and candidate countries

\begin{tabular}{|c|c|c|c|}
\hline Variables & B & Beta & $\mathrm{SE}$ \\
\hline Constant & 6.331 & & .356 \\
\hline Age & .002 & .014 & .001 \\
\hline Gender & .210 & $.049 * *$ & .028 \\
\hline \multicolumn{4}{|l|}{ Economic } \\
\hline HH Income & .000 & -.010 & .000 \\
\hline Deprivation Scale & -.162 & $-.141 * *$ & .012 \\
\hline Make ends meet & -.301 & $-.192 * *$ & .015 \\
\hline Food & .238 & $.039 * *$ & .047 \\
\hline \multicolumn{4}{|l|}{ Social cohesion } \\
\hline General trust & .140 & $.150 * *$ & .007 \\
\hline Trust Government & -.082 & $-.064 * *$ & .010 \\
\hline Conflict scale & .011 & .012 & .007 \\
\hline \multicolumn{4}{|l|}{ Social inclusion } \\
\hline Support ill & -.024 & -.001 & .113 \\
\hline Support advice & .016 & .001 & .094 \\
\hline Support depressed & .114 & .010 & .085 \\
\hline Support money & .075 & .012 & .046 \\
\hline Married & .287 & $.065^{* *}$ & .030 \\
\hline Contact parents & .011 & .009 & .009 \\
\hline Contact children & -.001 & -.001 & .008 \\
\hline Contact friends & .061 & $.032 * *$ & .013 \\
\hline Relatives/friends letter etc. & .092 & $.017 *$ & .039 \\
\hline Feel left out & .307 & $.122 * *$ & .019 \\
\hline Vote & -.082 & -.015 & .038 \\
\hline Meeting TU etc. & .004 & .001 & .040 \\
\hline \multicolumn{4}{|l|}{ Empowerment } \\
\hline Life complicated & .291 & $.140 * *$ & .017 \\
\hline Health & -.247 & $-.131 * *$ & .015 \\
\hline Education & -.110 & $.034 * *$ & .025 \\
\hline \multicolumn{4}{|l|}{ Countries } \\
\hline Belgium & -.101 & -.009 & .089 \\
\hline Denmark & .053 & .006 & .085 \\
\hline Germany & -.334 & $-.034 * *$ & .085 \\
\hline Greece & .067 & .006 & .100 \\
\hline Spain & -.033 & .003 & .092 \\
\hline France & -.355 & $-.036 * *$ & .086 \\
\hline Ireland & -.270 & -.018 & .113 \\
\hline Italy & -.247 & $-.023 *$ & .092 \\
\hline Luxembourg & -.190 & -.011 & .124 \\
\hline Netherlands & -.174 & -.017 & .089 \\
\hline Austria & -.086 & -.009 & .083 \\
\hline Portugal & -.785 & $-.072 * *$ & .095 \\
\hline Finland & .123 & .013 & .083 \\
\hline
\end{tabular}


Table 4 continued

$* p<.001 ; * * p<.001$

Reference country is Sweden

\begin{tabular}{lclc}
\hline Variables & $\mathrm{B}$ & Beta & $\mathrm{SE}$ \\
\hline Great Britain & -.198 & -.016 & .097 \\
Cyprus & -.115 & -.007 & .119 \\
Czech Republic & -.498 & $-.041^{* *}$ & .099 \\
Estonia & -.365 & $-.025^{* *}$ & .114 \\
Hungary & -.742 & $-.068^{* *}$ & .095 \\
Latvia & -.526 & $-.044^{* *}$ & .102 \\
Lithuania & -.564 & $-.045^{* *}$ & .045 \\
Malta & -.288 & -.017 & .123 \\
Poland & .168 & .013 & .104 \\
Slovakia & -.796 & $-.075^{* *}$ & .092 \\
Slovenia & -.259 & -.020 & .103 \\
Bulgaria & -1.150 & $.098^{* *}$ & .103 \\
Romania & -.049 & -.005 & .092 \\
Adjusted $R^{2}$ & .479 & & \\
\hline
\end{tabular}

\section{Conclusions}

In this paper we have argued that Social Quality, a model derived from sociological theory, can be used to derive a parsimonious set standardised indicators to explain a large part of the variance in individual life satisfaction. We selected indicators for each quadrant of the model and demonstrated that our model is stable over time and for the 27 countries of the EU (between 2003 and 2007) despite significant variations in life satisfaction between countries. This suggests that although the levels of life satisfaction may be different, the factors that determine it selected to represent the Social Quality model, are stable across time and place. In all countries, people need to have economic security, social cohesion, social inclusion and to be empowered to control their lives in order to be satisfied with their lives. The indicators are theoretically linked to measure underlying social constructs that go beyond the individual variables themselves and beyond the simple accumulation of multiple indicators. However, in some countries, these factors are more prevalent than in others and therefore there are more people with higher levels of satisfaction.

The aim of this paper was only to establish the Social Quality model as an explanation of life satisfaction. We have not used it to explain differences between societies or between social groups However, the model could enable us to look more closely at what quality of life might mean for different social groups (such as the employed, the unemployed, ethnic minorities, the elderly, the young) or between different societies and regions. Nor have we attempted to combine subjective and objective indicators for this paper (for example by including Gini coefficients) and this challenge, along with that of disentangling the individual and country level differences through multi-level modelling will have to wait for future research. However, we have shown that the Social Quality model could also be a useful policy instrument by which governments could ensure the maximum quality of life of their populations. The implication is that the policies that are needed to deliver Social Quality and to raise levels of life satisfaction are quite consistent in all European countries and can be identified. Therefore, they can be used as a basis for social policies. 
Table 5 Country differences in subjective satisfaction (OLS regression) 2007 wider EU

\begin{tabular}{|c|c|c|c|}
\hline Variables & B & Beta & SE \\
\hline Constant & -13.793 & & 3.064 \\
\hline Age & .005 & $.043 * *$ & .001 \\
\hline Gender & .109 & $.026 * *$ & .026 \\
\hline \multicolumn{4}{|l|}{ Economic } \\
\hline HH Income & .000 & -.014 & .000 \\
\hline Deprivation scale & -.145 & $-.117 * *$ & .011 \\
\hline Make ends meet & -.255 & $-.161 * *$ & .013 \\
\hline Food & .262 & $.038 * *$ & .047 \\
\hline \multicolumn{4}{|l|}{ Social cohesion } \\
\hline General trust & .071 & $.082 * *$ & .006 \\
\hline Trust Government & .079 & $.096 * *$ & .006 \\
\hline Conflict scale & .013 & $.017 *$ & .005 \\
\hline \multicolumn{4}{|l|}{ Social inclusion } \\
\hline Support ill & -.451 & $-.027 * *$ & .106 \\
\hline Support advice & -.098 & -.008 & .081 \\
\hline Support depressed & -.160 & -.016 & .065 \\
\hline Support money & -.169 & $-.028 * *$ & .039 \\
\hline Married & .279 & $.065 * *$ & .027 \\
\hline Contact parents & .014 & .003 & .030 \\
\hline Contact children & .037 & .009 & .029 \\
\hline Contact friends & .074 & .014 & .033 \\
\hline Relatives/friends letter etc. & .141 & $.022 * *$ & .041 \\
\hline Feel left out & .265 &. .127 & .015 \\
\hline Vote & -.019 & -.007 & .017 \\
\hline Meeting TU etc. & .009 & .001 & .039 \\
\hline \multicolumn{4}{|l|}{ Empowerment } \\
\hline Life complicated & .264 & $.147 * *$ & .013 \\
\hline Health & -.293 & $-.134 * *$ & .016 \\
\hline Education & -.076 & $-.021 *$ & .025 \\
\hline \multicolumn{4}{|l|}{ Countries } \\
\hline Belgium & -.064 & -.006 & .084 \\
\hline Denmark & -.197 & -.020 & .081 \\
\hline Germany & .619 & $.080 * *$ & .073 \\
\hline Greece & .758 & $.073 * *$ & .080 \\
\hline Spain & .622 & $.046 * *$ & .099 \\
\hline France & .221 & $.025^{*}$ & .077 \\
\hline Ireland & .140 & .009 & .107 \\
\hline Italy & .569 & $.044 * *$ & .097 \\
\hline Luxembourg & .096 & .007 & .097 \\
\hline Netherlands & .203 & .020 & .081 \\
\hline Austria & .737 & $-.061 * *$ & .092 \\
\hline Portugal & 1.117 & $.074 * *$ & .108 \\
\hline Finland & -.118 & -.012 & .082 \\
\hline
\end{tabular}


Table 5 continued

\begin{tabular}{lrcc}
\hline Variables & B & Beta & SE \\
\hline Great Britain & -.187 & .016 & .084 \\
Cyprus & .063 & .006 & .092 \\
Czech Republic & .506 & $.049^{* *}$ & .086 \\
Estonia & .545 & $.047^{* *}$ & .091 \\
Hungary & 1.111 & $-.100^{* *}$ & .090 \\
Latvia & .605 & $.046^{* *}$ & .099 \\
Lithuania & .425 & $.036^{* *}$ & .092 \\
Malta & -.063 & -.005 & .097 \\
Poland & -.019 & -.002 & .087 \\
Slovakia & .455 & $.043^{* *}$ & .087 \\
Slovenia & .236 & $.021^{*}$ & .088 \\
Bulgaria & 1.140 & $.083^{* *}$ & .105 \\
Romania & .187 & .016 & .093 \\
Adjusted $R^{2}$ & .425 & & \\
\hline
\end{tabular}

$* p<.001 ; * * p<.001$

Reference country is Sweden

Acknowledgments We would like to thank the European Foundation for the Improvement of Living and Working Conditions for access to the European Quality of Life surveys.

Open Access This article is distributed under the terms of the Creative Commons Attribution Noncommercial License which permits any noncommercial use, distribution, and reproduction in any medium, provided the original author(s) and source are credited.

\section{References}

Abbott, P., \& Wallace, C. (2010). Explaining economic and social transformations in Post-Soviet Russia, Ukraine and Belarus: The social quality approach. European Societies, 12(5), 653-674.

Abbott, P., Sapsford, R., \& Wallace, C. (2011). Surviving the transformation: Social quality in Central Asia and the Caucasus. Journal of Happiness Studies, 12(2), 199-223.

Anderson, R., Branislav, M., Vermeylen, G., Lyly-Yrjanainen, M., \& Zigante, V. (2009). Second European quality of life survey-overview. Dublin: European Foundation for the Improvement of Living and Working Conditions.

Beck, W. L., Van der Maesen, \& Walker, A. (1997). The social quality of Europe. The Hague: Kluwer Law International.

Bohnke, P. (2006). First European quality of life survey: Life satisfaction, happiness and sense of belonging. Dublin: European Foundation for the Improvement of Living and Working Conditions.

Diener, E., \& Suh, E. (1997). Measuring quality of life: Economic, social and subjective indicators. Social Indicators Research, 40, 189-216.

Giddens, A. (1984). The constitution of society. Outline of a theory of structuration. Cambridge: Polity Press.

Haller, M., \& Hadler, M. (2006). How social relations and structures can produce happiness and unhappiness: An international comparative analysis. Social Indicators Research, 75, 169-216.

Halpern, D. (2010). The hidden wealth of nations. Cambridge: Polity Press.

Lockwood, D. (1992). Solidarity and schism: The problem of disorder in Durkheimian and Marxist sociology. Oxford and New York: Oxford University Press.

Mills, C. W. (1954). The sociological imagination. Harmondsworth: Penguin.

Nussbaum, M. C., \& Sen, A. (Eds.). (1993). The quality of life. Oxford: Clarendon Press.

Phillips, D. (2006). Quality of life. Concept, policy, practice. London and New York: Routledge.

Richardson, D., Hoelscher, P., \& Bradshaw, J. (2008). Child well-being in Central and Eastern European Countries and the Commonwealth of Independent States. Child Indicators Research, 1, 211-250. 
Sen, A. (1993). Capability and well-being. In M. C. Nussbaum \& A. Sen (Eds.), The quality of life. Oxford: Clarendon Press.

Sen, A. (1999). Development as freedom. New York: Anchor Books.

Tarling, R. (2009). Statistical modelling for social researchers: Principles and practice. London: Routledge.

Veenhoven, R. (1999). Quality of life in an individualistic society. A comparison of 43 nations in the early 1990 s. Social Indicators Research, 48, 157-186.

Veenhoven, R. (2002). Why social policy needs subjective indicators. Social Indicators Research, 58, $33-45$.

Veenhoven, R. (2008). Sociological theories of subjective well-being. In M. Eid \& R. Larson (Eds.), The science of subjective well-being. A tribute to Ed Diener. New York: Guildford.

Watson, D., Pichler, F., \& Wallace, C. (2009). Subjective well-being in Europe. Dublin: European Foundation for the Improvement of Living and Working Conditions. 